\title{
5 Putting the Rural World on the Road of Progress? Experiences of Failure by Local Activists of the Belgian Education League (c. $1865-1884$ )
}

"Just as last year, our circle is sleeping", wrote an education activist from the small town of Veurne in West Flanders, in a letter to the General Council of the Belgian Ligue de l'Enseignement ('Education League') in Brussels. ${ }^{1}$ This was the type of message that Charles Buls (1837-1914), secretary general of the Belgian Education League, read often ever since his association had begun to found branches in different localities all over the country. However, many local circles knew of a short period of enthusiasm and vibrant activity that found expression in their early messages to the centre. So did the branch in Veurne. In February 1869, shortly before his announcement of the "sleeping circle", the correspondent in Veurne had reported on a very successful public seminar in town, which had taken place on a Sunday and attracted a big audience. He enthusiastically set about expanding the local circle's activities from Veurne to the countryside. ${ }^{2}$ This spatial expansion was exactly what the founders of the Belgian Education League, Charles Buls and other freethinkers from Brussels, had had in mind when they set up the association in 1865. Members living in the same locality were encouraged to create local circles to "initiate discussions" about education reform and "serve the League's interests" in the provinces while regularly reporting to the General Council in Brussels. ${ }^{3}$ In a letter to a local circle in 1866, Buls claimed that his "biggest desire" was the League's decentralisation and its local members' participation. ${ }^{4}$ By building up a structure of local associations, the Belgian ligueurs followed their model organisation, the Dutch Maat-

1 M. Nihoul to Charles Buls, Veurne, 1869, 501,I Sections locales, Archives of the Ligue Belge de l'Enseignement (Ar.LB), Brussels, Belgium. Recently , the archives of the Ligue were transferred to the city archives of Brussels (Archives de la Ville de Bruxelles). All municipalities formally recognised as "villes" by Royal Act in 1825 will be referred to as 'towns' or as 'cities' if they have more than 100.000 inhabitants.

2 M. Nihoul to Charles Buls, Veurne, 13 February 1869, 501,I Sections locales, Ar.LB.

3 Ligue belge, Circular, 10 June 1865, 101/102 Assemblée générale, Ar.LB.

4 Charles Buls to secretary of local circle, Brussels, 08 October 1866, 202 Conseils généraux, Ar.LB.

Ә OpenAccess. ( 2019 Christina Reimann, published by De Gruyter. (cc) BY-NC-ND This work is licensed under the Creative Commons Attribution-NonCommercial-NoDerivatives 4.0 License. https://doi.org/10.1515/9783110581546-005 
schappij tot Nut van 't Algemeen ('Society for Public Welfare'), founded in $1784 .{ }^{5}$ Between 1815 and the Belgian independence in 1830, the Tot Nut tried, albeit without meaningful success, to establish circles in the Southern parts of the Netherlands. ${ }^{6}$

Nor did the Belgian Education League achieve its decentralisation plan. This chapter argues that attempts to establish local circles can altogether be regarded as a failure. It thereby partly counters earlier interpretations according to which the Belgian League was a national organisation that was sustained by firm roots in the localities. ${ }^{7}$ While the Belgian Ligue de l'Enseignement has been the object of extensive research, ${ }^{8}$ its lack of local embeddedness has not yet been under close scrutiny. This is a shortcoming insofar as such an analysis opens new perspectives on the Belgian education reform movement as a whole. Most importantly, new insight can be gained by integrating living testimonies from local activists stored in the League's archives but that have not yet been looked into by historians. This chapter therefore sets out to tell the story of the Education League's failure to integrate the countryside as it was experienced by the local activists. It shall zoom into the living worlds of these actors by using their letters to the association's centre in Brussels. These accounts depict how local activists un-

5 Carmen Van Praet and Christophe Verbruggen, “ 'Soldiers for a Joint Cause'. A Relational Perspective on a Local and International Educational Leagues and Associations in the 1860s," BMGN - Low Countries Historical Review 130, no. 1 (2015): 17.

6 Van Praet and Verbruggen, “'Soldiers for a Joint Cause'," 8-9.

7 Christophe Verbruggen and Carmen Van Praet see the Belgian Education League, in line with the Tot Nut and the French and Italian Education Leagues as " [...] fine examples of nationally organized but locally embedded socio-cultural structures of sociability [...]”. See: Van Praet and Verbruggen, “ 'Soldiers for a Joint Cause',” 22.

8 Jacques Lory's study on primary education contains a detailed and source-based presentation of the Belgian Education League. See: Jacques Lory, Libéralisme et instruction primaire (18421879) (Leuven: Editions Nauwelaerts, 1979). Éliane Gubin has written on the connections between the League and feminist education movements. See: Éliane Gubin, "Libéralisme, féminisme et enseignement des filles en Belgique aux 19e-début 20e siècles,” in Politiques, imaginaires et education. Mélanges en l'honneur de Jacques Lory, eds. Jean-Pierre Nandrin and Laurence van Ypersele (Brussels: Facultés Universitaires Saint-Louis, Cahiers $n^{\circ} 13-14,2000$ ), 151-174. Detailed and well-documented self-presentations of the League can be found in the volumes edited by the Ligue Belge de l'Enseignement. See: La Ligue de l'Enseignement et la défense de l'éducation publique avant 1914 (Brussels: Ligue de l'Enseignement et de l'Education Permanente asbl, 1986); Histoire de la Ligue de l'Enseignement et de l'Éducation permanente, 18641989 (Brussels: Ligue de l'Enseignement, 1990). For a transnational and timely comparison of education debates, see: Jeffrey Tyssens, "Onderwijsconflict en -pacificatie vanuit een comparatief perspectief. België, Nederland, Frankrijk," in Het schoolpact van 1958. Ontstaan, grondlijnen en toepassing van een Belgisch compromis, eds. Els Witte, Jan de Groof and Jeffrey Tyssens (Brussels: VUB Press, 1999), 39-86. 
derstood their unsuccessful endeavours to mobilise fellow townspeople or villagers for the cause of popular education. An analysis of these letters helps to explain why the otherwise successful and lively Education League did not develop a lasting sociability in the provinces. It will also tell us about the spatial configuration of the 'school war' (1879-1884) and its precursors, by assessing how the national struggle about secular and Catholic education took place outside of Brussels. ${ }^{9}$ This chapter argues that it was not least because of a social and cultural divide and mismatch between the capital and the provinces in general and the rural regions in particular that the Ligue de l'Enseignement failed to establish a long-lasting network outside Brussels. The League's representatives in the provinces were not able to bridge the gap between the ideological-driven centre of the League, which was embedded in the liberal-minded bourgeoisie, and the rural and provincial population strongly influenced by the Catholic clergy and for the most part taken up by familial maintenance. The local activists were themselves caught between these two mind-sets, a sentiment that marked their experience of their failure.

The notion of experience, as developed by John Dewey, will be used as an analytical tool to interpret the written accounts of local education activists. This chapter proceeds from Dewey's premise that "every genuine experience has an active side which changes in some degree the objective conditions under which experiences are had". ${ }^{10}$ An experience being therefore situated at the intersection between the subjective and the social, ${ }^{11}$ this analytical perspective allows this chapter to assess the failure of the Education League in the provinces both within its socio-political context and at the individual level, as represented by grassroots activists. A genuine experience ("Erfahrung”) develops from lived experience ("Erlebnis") by being reinterpreted and placed within a meaningful context. In this way, experience becomes a dynamic and continuous process. ${ }^{12}$ The act of reporting and writing about lived events is an integral part of the creation of experience, which also comprises the perception and interpretation

9 For a detailed assessment of the sharp conflict between liberals and Catholics, and the Catholic resistance against the liberal reforms in and around the town of Tournai, Hainaut, see: JeanLuc Soete, "La Résistance catholique à la Loi van Humbeeck dans l'arrondissement de Tournai (1878-1884)," Revue Belge d'Histoire Contemporaine 11, no. 1-2 (1980): 119-169.

10 John Dewey, Experience and Education (New York: Simon \& Schuster, 1997[1938]), 15.

11 André Zeitler and Jean-Marie Barbier, "La notion d'éxpérience, entre langage savant et langage ordinaire," Recherche et formation 70, no. 2 (2012): 107-118, 109.

12 Zeitler and Barbier, "La notion d'éxpérience," 109. 
of an initial event. ${ }^{13}$ In line with Dewey's definition, this chapter focuses on the individual 'making-sense-of-one's-world'-aspect of experiences while also considering a closely linked feature, namely the socially constructive character of reality, on which notions of experience also rest. ${ }^{14}$

In total, this investigation takes into account all 28 local circles which between 1865 and 1884 communicated with the association's centre in Brussels. Source material consists of letters and reports received by the General Council as well as of circulars and letters sent out by the central committee. Unfortunately, response letters from the General Council to the local activist are, with some rare exceptions, not contained in the League's records.

\section{Contextualising the birth and failures of the Belgian Education League}

The Ligue de l'Enseignement was one of the most visible associations within the education reformist movement in late $19^{\text {th }}$-century Belgium. With its petition campaigns, its public conferences and meetings, its visibility in the national media, and thanks to their well-known spokesmen, the League became the strongest voice on behalf of the liberal-progressive education reform movement. It strove for an in-depth reform of the 1842 Primary Education Act and for the introduction of general, public education that should be secular, free of charge and compulsory. The League professed an aim to spread primary education among the working classes and to foster the education of women and girls, while also presenting itself as representative of the teachers' interests. When it started its activities in 1865, the Ligue stood in favour of a decentralised, civil society-based education system, but quickly pivoted to support for a centralised and state-focused system. The 1879 Education Act, enacted by the Liberal government under Walthère Frère-Orban (1812-1896) and with the League member Pierre van Humbeéck (1829-1890) at the head of the new Ministry for Education, implemented large parts of the League's agenda. Most of these reforms were reversed when the 1884 elections brought the Catholic party back to power. As the League lost its strong voice in education politics, it tried to safeguard the secular

13 Ulrike Wunderle, "Wissenschaftsgeschichte als Erfahrungsgeschichte (Tübingen, 0102.12.2000)," H-Soz-u-Kult, last modified November 11, 2001, https://www.hsozkult.de/confer encereport/id/tagungsberichte-12.

14 See: Peter Berger and Thomas Luckmann, The Social Constitution of Reality. A Treatise in the Sociology of Knowledge (Newburyport: Open Road Media, 2011). 
public schools, which the League believed were threatened by the Catholic government. While its standing in the national public sphere was vanishing, the Ligue remained connected within a transnational network of education reformists, maintaining close contacts with the French and English national education leagues in particular. ${ }^{15}$ The League grew again in importance during the interwar years ${ }^{16}$ and still exists as a francophone organisation today. ${ }^{17}$

M. Nihoul's message from 1869, quoted at the start of this chapter, observed that the local circle of Veurne had been "sleeping" over the last two years, a summary of the League's situation outside of the capital. Yet, like the circle in Veurne, many local branches experienced some moments of enthusiasm and vibrant activity. But the bulk of the reports the local activists sent to the General Council in Brussels contained representations and justifications of their failure. The circles in the city of Liège ${ }^{18}$ and in the town of Dendermonde in East Flanders were dissolved as early as 1872 . While some branches, such as the ones in the municipality of Waterloo and the city of Antwerp, were revitalised when the Liberals came to power in 1879, the League's sparse activity outside of Brussels completely vanished from 1880 onward. League records do not contain any trace of the existence of local circles after 1883. So in fact, the Belgian Education League was a Brussels organisation. Most of the League's branches and, in particular, the League's General Council, were formed by the liberal-minded political and intellectual elite of the Brussels bourgeoisie. Even before Charles Buls, the League's founder, its long-time secretary general, and finally president, was elected mayor of Brussels, the League cultivated a close relationship with the capital's administration. ${ }^{19}$

The association's failure to mobilise followers outside the capital coincided with the politicisation of the countryside in late $19^{\text {th }}$-century Europe. In Belgium as in other European countries, political parties, associations and mutual societ-

15 Christina Reimann, Schule für Verfassungsbürger? Die Bildungsligen und der Verfassungswandel des späten 19. Jahrhunderts in Belgien, England und Frankreich (Münster/New York: Waxmann, 2016), 12-27.

16 Jeffrey Tyssens, Strijdpunt of pasmunt? Levensbeschouwelijk links en de schoolkwestie, 19181940 (Brussels: VUB Press, 1993), 241-257.

17 https://ligue-enseignement.be. Visited on 21/07/2017.

18 For more detail on the Liège branch, see: Léon. E. Halkin, "La section liégeoise de la Ligue de l'enseignement en 1865-1866," in Mélanges offerts à G. Jacquemyns (Brussels: Editions de l'Institut de Sociologie, 1968), 415-419.

19 Tyssens, Strijdpunt of pasmunt?, 236. 


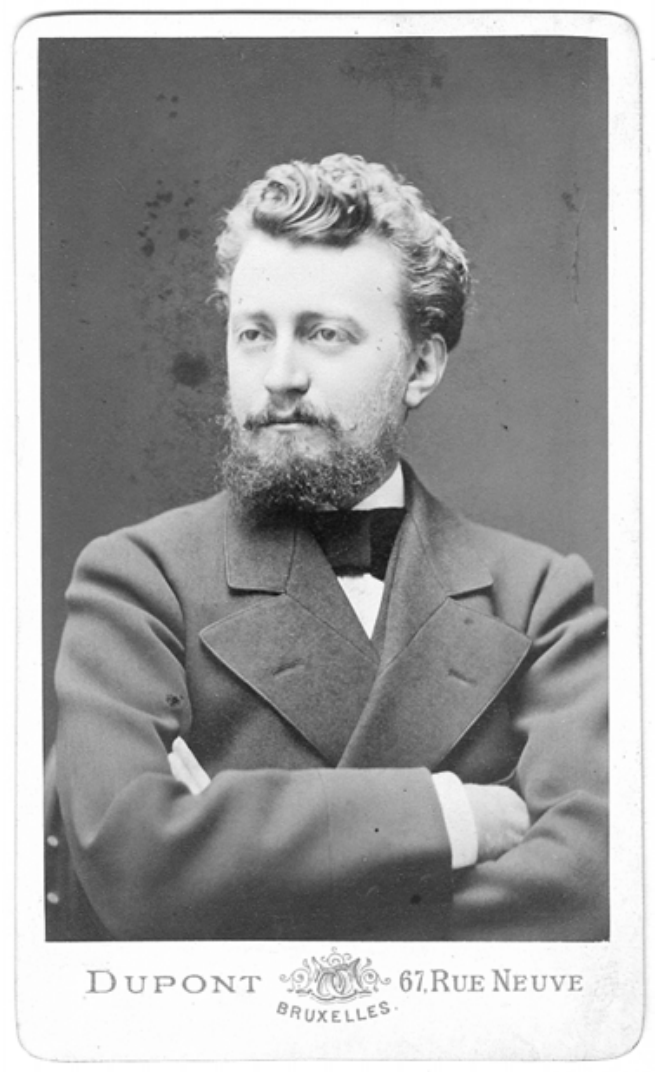

Figure 5.1: Pierre van Humbeéck (1829-1890), a long-time member of the League's General Council who became the first Minister of Public Education in 1879 (Liberas/Liberaal Archief)

ies were penetrating the rural areas organisationally and ideologically. ${ }^{20}$ The Ligue de l'Enseignement was one of the many organisations that since the midcentury had endeavoured to expand its networks and activities beyond the capital and the urban centres. ${ }^{21}$ The Willemsfonds, for example, an association

20 Gunther Mai, "Die Agrarische Transition. Agrarische Gesellschaften in Europa und die Herausforderungen der industriellen Moderne im 19. und 20. Jahrhundert," Geschichte und Gesellschaft 33, no. 4 (2007): 489.

21 For the case of the Belgian Workers' Party, see: Guy Vanschoenbeek, “The Workers' Party Against the Farmers' League. Social Democracy and the Peasantry in Belgium, 1893-1914,” in Urban Radicals, Rural Allies. Social Democracy and the Agrarian Issue, 1870-1914, ed. Aad Blokland (Bern: Peter Lang, 2002), 145-161. 
founded in 1851 in Ghent with the aim of promoting the Dutch language, also started to erect local circles starting in $1862^{22}$ - a coincidence that had an impact on the League's decentralisation project in Flanders. The politicisation of the Belgian provinces also consisted of the step-by-step democratisation of the local elections. Unlike on the national level, municipal elections were expanded by law in 1836; especially in the smaller wards, local election campaigns integrated and mobilised an increasing number of inhabitants. ${ }^{23}$ At the same time, the consolidation of the Belgian territorial nation-state was fostered by the establishment of a dense railway network. ${ }^{24}$ Cheap railway ticket prices enabled people living in the countryside to commute to urban industrial centres and to maintain their rural living style while working in the industries. ${ }^{25}$ Especially with the advent of the agricultural crisis, which started in 1873, the Belgian industries attracted a growing number of workers. However, despite improved infrastructure and increased mobility, the mental and cultural gap between farmers/villagers and city dwellers grew as the century progressed. ${ }^{26}$ The mismatch between the capital and the provinces in general and the rural regions in particular played its part in the Ligue de l'Enseignement's failure outside Brussels.

In fact, the Education League was far more successful in urban centres than in smaller towns or rural areas. A municipality's size was crucial insofar as competition with an already existing association was more likely to hamper the establishment of a local circle in smaller municipalities - a fact that was even relevant for the city of Antwerp where the the local bourgeois freethought society initially resisted the League's initiative of setting up a local circle. ${ }^{27}$ The finally established branch in Antwerp 'woke up' anew after the elections of 1878 that brought the Liberal Party to power on the national level; it continued its work

22 Van Praet and Verbruggen, “'Soldiers for a Joint Cause'," 18.

23 Éliane Gubin and Patrick Lefèvre, "Lens, un canton rural en Hainaut vers 1850," in La Belgique rurale du Moyen-Age à nos jours. Mélanges offerts à Jean-Jacques Hoebanx (Brussels: Editions de l’Université de Bruxelles, 1985), 321-351, 346.

24 On the integration of nation-states through infrastructure, see: Charles S. Maier, "Consigning the Twentieth Century to History. Alternative Narratives for the Modern Era," The American Historical Review 105, no. 3 (2000): 807-831; Jörg Ganzenmüller and Tatjana Tönsmeyer, eds., Vom Vorrücken des Staates in die Fläche. Ein europäisches Phänomen des langen 19. Jahrhunderts (Cologne: Böhlau-Verlag, 2016).

25 Vanschoenbeek, “The Workers' Party Against the Farmers’ League,” 146-147.

26 Henk De Smaele, Rechts Vlaanderen. Religie en stemgedrag in negentiende-eeuws België (Leuven: Universitaire Pers Leuven, 2001), 375-376.

27 Lory, Libéralisme et instruction primaire, I, 350-351, 391. 
until the 1880s, longer than any other local circle. ${ }^{28}$ The local circle in the industrial city of Liège was by far the most active before it announced its dissolution in 1872 due to a lack of financial resources. ${ }^{29}$ It had prepared petitions, ${ }^{30}$ held regular meetings and kept close contact with the General Council in Brussels. ${ }^{31}$ However, even though those local branches in Liège and Antwerp were relatively successful when compared to other local circles, they were still insignificant compared to the association's centre in Brussels.

Except for Luxembourg and Limburg, local circles were established in every province, with a concentration in the provinces of Walloon Brabant ${ }^{32}$, Hainaut and Liège, the industrial regions in the centre of the country. Flanders was less integrated into the League's network. One major reason for this was that, on the background of a strengthening Flemish movement, the League appeared as outrightly francophone. Publicly as well as with - even Flemish - correspondents its leading figures communicated almost exclusively in French while their project of fostering the Dutch language was soon relegated to the background..$^{33}$ As the organisation increasingly refocused on Wallonia, the Council almost completely neglected the Flemish language, which the League had once set out to protect. ${ }^{34}$ Another factor that hampered the establishment of local circles in Flanders was the presence of the Willemsfonds. Like the League, this association set up popular libraries ${ }^{35}$ and took initiatives to improve popular education such as conferences coupled with music concerts. ${ }^{36}$ In the Willemsfonds' founding city of Ghent, the League was unable to establish a local circle because of the Wil-

28 Local circle in Antwerp to General Council, Antwerp, 13 March 1881, 501,I Sections locales, Ar.LB.

29 Local circle in Liège to Charles Buls, Liège, 1872, 501,I Sections locales, Ar.LB.

30 Local circle in Liège to Charles Buls, Liège, 20 November 1867, 501,I Sections locales, Ar.LB; Local circle in Liège, Annual Report 1868-1869, Liège, 1869, 501,I Sections locales, Ar.LB.

31 Local circle in Liège, Annual Report, Liège, 7 June 1868, 501,II Sections locales, Ar.LB.

32 In 1995, the province of Brabant was split into Flemish Brabant, Walloon Brabant and Brussels Capital Region. In the rest of this chapter we will refer to the current provinces.

33 On the relationship between the League and the Flemish movement see: René Robrecht, "La Ligue et le mouvement flamand," Éduquer 35 (2001): 26-27.

34 Member in West Flanders to General Council, 1867, 202 Conseils généraux, Ar.LB.

35 For the League's actions in favour of public libraries, see: Bruno Liesen, Bibliothèques populaires et bibliothèqeus publiques en Belgique (1860-1914). L'action de la Ligue de l'Enseignement et le réseau de la ville de Bruxelles (Liège: Editions du C.L.P.C.F., 1996).

36 Luc Pareyn, "Het Willemsfonds en de volksontwikkeling," in Marcel Bots e.a., Het Willemsfonds van 1851 tot 1914 (Ghent: Liberaal Archief, 1993), 185-221; Jos Daelman, "De volksbiblioheken van het Willemsfonds,” in Het Willemsfonds van 1851 tot 1914, 223-250. 
lemsfonds' resistance as the latter thought the League too francophone. ${ }^{37}$ Nonetheless, the League started cooperating with the Willemsfonds in Ghent, ${ }^{38}$ as did the local circle in Bruges, which only survived thanks to this collaboration as well as to the liberal dominance in this town. ${ }^{39}$ In fact, a municipality's liberal orientation reflected in its local politics and in its social and cultural public life favoured the Leagues' endeavours to a large extent. Thus, Flemish liberal strongholds like Ypres in West Flanders or places with a rich liberal associational life such as Menen hosted comparatively long lasting, more or less dynamic local circles despite the general restrictions to the League's activity in Flanders. ${ }^{40}$ However, this explanation should not be overstretched, as the opposite could be also true, as shown by Kortrijk in West Flanders where the local circle was relatively long lasting despite the town having been continuously governed by Catholics since 1864. Thus, in order to understand the failure of the many local activists, one has to look beneath the level of political, religious or language issues into the actors' individual, locally embedded experiences that were sometimes unrelated to the socio-political conditions.

I shall also argue that the League's failure to expand outside Brussels cannot simply be explained as an effect of the association's centralising statutes, although these surely contributed to inhibiting the development of independent reform action in the peripheral areas. ${ }^{41}$ According to the League's constitution, all local branches had to transfer at least one third of their incoming membership fees to the centre in Brussels. Local representatives sitting in the meetings of the General Council were only given a non-voting position. The League's weakness outside the capital - as well as the insignificance of its Brussels branch was also connected to its generally low degree of internal democracy. ${ }^{42}$ All regular members were excluded from the decisions taken by the General Council. This body, composed of 33 members who were annually elected by the members' General Assembly, was responsible for all of the League's business. Among its members, the Council elected a bureau of seven members who dealt with the League's daily business. The same centralised structure was established in the local circles, prompting one member of the local Brussels circle to complain

37 Carmen van Praet, "Liberale hommes-orchestres en de sociale kwestie in de negentiende eeuw. Tussen lokaal en internationaal” (PhD diss., University of Ghent, 2015), 343-345.

38 Van Praet, "Liberale hommes-orchestres," 346.

39 Local circle in Bruges, Annual Report 1876, Bruges, 29 August 1876, 501,I Sections locales, Ar.LB.

40 De Smaele, Rechts Vlaanderen, 385-389.

41 Tyssens, Strijdpunt of pasmunt?, 239; Reimann, Schule für Verfassungsbürger, 100-103.

42 Reimann, Schule für Verfassungsbürger, 103-106. 
about the regular members' passivity and suggest a reform of the circle's internal organisation. ${ }^{43}$ Still another member, from Brussels as well, pointed to the League's "anti-democratic" character as the reason for his withdrawal. ${ }^{44}$

However, the League's failure in the provinces in general and in the rural areas in particular was also due to specific local conditions. People experienced the association as a series of fundamental mismatches between the association's Brussels-based identity and life outside the capital, in villages and in smaller towns. While a number of local activists were conscious of the League's centralised structure and the negative effects of that centralisation on their own work, ${ }^{45}$ they largely blamed local circumstances - their lived experiences - for the failure of local League operations. This chapter therefore considers how local activists presented and justified their failure within the context of tension between the League's agenda and local living and working conditions. The first part assesses the positive experiences some ligueurs depicted, positive experiences embedded in their living conditions and the local power structures. Subsequently, I shall analyse the local activists' daily experiences that complicated and sometimes hindered the League's establishment in the provinces: the power of the Catholic clergy and the particular rhythm of social and political life in villages and small towns.

The Belgian League's inability to embed itself in the provinces becomes even more apparent when compared to the French Ligue de l'Enseignement, which was deeply entrenched in small towns and in the countryside. ${ }^{46}$ At different points in this analysis, I shall therefore compare and draw parallels between French and Belgian developments. The French Education League was initiated by Jean Macé (1815-1894), the director of a boarding school and founder of a public library in Alsace; he was a teacher, a journalist and an author of pedagogical literature. ${ }^{47}$ As the director of a public library, he came into contact with the Belgian Educa-

43 Member from Brussels to Local circle in Brussels, 1873, 501,I Sections locales, Ar.LB.

44 A. Vancauberge to Charles Buls, Brussels, 23 December 1880, 800 Personnes physiques, Ar.LB.

45 Local circle in Gembloux, Circular, Gembloux, 27 January 1875; Local circle in Liège, Annual Report 1868-1869, Liège, 1869, 501,I Sections, Ar.LB.

46 The most extensive work on the French Education League is the unpublished $\mathrm{PhD}$ thesis by Jean-Paul Martin: "La Ligue de l'enseignement et la République des origins à 1914” (PhD diss, Institut d'études politiques, Paris, 1992). See also Martin's numerous articles on the League, in particular:"La Ligue de l'enseignement, la loi de 1901 et le champ politique républicain," in Associations et champ politique, eds. Claire Andrieu, Gilles Le Béguec and Danielle Tartakowsky (Paris: Publications de la Sorbonne, 2001), 459-475.

47 For a short portrait, see: Richard J. Johnston, “Jean Macé and the Fight for Public Education in Nineteenth-Century France,” Paedagogica Historica 12, no. 1 (1972): 59-80. 
tion League and joined the association. Since meeting at the General Assembly of the Belgian Ligue in Liège in 1866, Jean Macé and Charles Buls corresponded intensively with one another about their endeavours to promote popular education. In 1868, inspired by the Belgian Education League, Macé decided to start an equivalent movement in France and succeeded in doing so despite the politically hostile context of the authoritarian Second Empire. ${ }^{48}$

\section{Winning over local elites: The establishment of circles in the provinces}

Between 1865 and 1869, several local circles of the Belgian Education League experienced a short period of enthusiasm, which was not least constituted of their exuberant reporting about it. Reporting to the General Council in 1866, a correspondent from the village Nederzwalm, East Flanders, boasted that: "Everyone is waking up; the League has become a conversation topic in the pubs, in the streets, and at the dinner tables". ${ }^{49}$ The establishment of local circles was primarily made possible thanks to the personal network of Charles Buls. ${ }^{50}$ Buls' social contacts were rooted in his engagement in liberal circles, Freemasonry, and the freethought movement. Most of his correspondents in the provinces also identified themselves with the liberal milieu; some of them were members of those liberal associations that in 1875 were to form the Fédération des Associations Libérales. ${ }^{51}$ In La Hestre, a village in the province of Hainaut, Buls' contact person professed that a local circle would be easily set up because he could recruit members among the "notabilities of the Liberal Party in the surrounding municipalities". ${ }^{2}$ Thanks to Buls' close bonds to liberal newspapers, in the capital as well as in the provinces, ${ }^{53}$ a number of journalists and owners of local newspapers were among the League's supporters, helping to spread the League's

48 Edouard Petit, Jean Macé, sa vie, son œuvre (Paris: Librairie Aristide Quillet, 1919), 212-219. 49 Member in Nederzwalm to General Council, Nederzwalm, 9 July 1866, 501,I Sections locales, Ar.LB.

50 A. Frings to Charles Buls, Lincent, 21 September 1866, 501, I Sections locales; Albert Feemans to Charles Buls, Louvain, 26 October 1866, 501,I Sections locales, Ar.LB.

51 Éliane Gubin, Jean-Pierre Nandrin, "La Belgique libérale et bourgeoise," Nouvelle Histoire de Belgique. Vol. 1: 1830-1905 (Brussels: Editions Complexes, 2005), 41.

52 Member in La Hestre to Charles Buls, La Hestre, 9 March 1869, 501,I Sections locales, Ar.LB. 53 M. Gislain to Charles Buls, Nil St. Vincent, 28 September 1866, 501,I Sections locales, Ar.LB. 
education programme..$^{54}$ Journalists were also among the initiators of local circles, as in the town of Péruwelz, Hainaut. ${ }^{55}$ In fact, Buls' social network and his contacts with the press in particular were crucial for the association's establishment. The same holds true for the French League whose initiator, Jean Macé, had been a journalist himself during the Second Republic. Thus, when he started the education reformist movement in the late 1860s, he could rely on the support of liberal newspapers. ${ }^{56}$ Facilitated by a considerable liberalisation of the press laws in 1868, liberal newspapers, for instance L'Opinion National, were willing to publish Macé's texts, beginning with his 1866 call for the foundation of a French Education League based on the Belgian model. ${ }^{57}$ The editorial staff of L'Opinion National also worked as an intermediary between Macé and his early followers who, in the context of a repressive regime, sent their first letters of support to the newspaper's address. ${ }^{58}$

In addition to the liberal and journalistic milieu, the Belgian League's General Council communicated and cooperated with many other associations. Some, such as Masonic lodges - the League was in close contact with the Brussels lodge Les Amis Philanthropes - expressed ideological support for the League's programme. Others were directly concerned with popular education and, in some places, these associations even turned into branches of the League, such as De Toekomst ('The Future') in Antwerp or the Vrienden des Vooruitgangs ('Friends of Progress') in Bruges ${ }^{59}$ which then closely cooperated with the Willemsfonds. This branch had quite a bit of success thanks to its network: in 1876 it professed to having "a loyal audience assisting our seminars". ${ }^{60}$ This joint work was not a given. In Liège, the circle seemingly did not cooperate with the many societies which, according to a local member, were busy organis-

54 M. van der Flancken to Charles Buls, Péruwelz, 31 January 1867; Member in Bruges to Charles Buls, Bruges, 8 August 1865; M. Gislain to Charles Buls, Nil St. Vincent, 20 August 1866; Correspondent in Liège of Journal des étudiants, Liège, 21 November 1866, 501,I Sections locales, Ar.LB.

55 Editor of Echo de la Frontière Belge to Charles Buls, Péruwelz, 11 November 1865, 501,I Sections locales, Ar.LB

56 Reimann, Schule für Verfassungsbürger, 67-68.

57 Jean Macé, “La Ligue de l'Enseignement en Belgique,” L’Opinion National, 15 November 1866.

58 This becomes apparent from Macé's correspondence stocked in the archives of the Institut Catholique in Paris.

59 Van Praet and Verbruggen, “'Soldiers for a Joint Cause'," 17.

60 Local circle in Bruges, Annual Report 1876, Bruges, 29 August 1876, 501,I Sections locales, Ar.LB. 
ing evening courses for working-class townspeople. ${ }^{61}$ It was an important aspect of the Belgian League's self-conception that a local circle was started from scratch and inaugurated with a ceremony organised by the General Council. Such a ceremony took place in 1868 in Dendermonde in East Flanders: The inauguration speech was given by Raymond Dedeyn (1834-), a member of the League's General Council. Then, the League's president, Jules Tarlier (1825-1870), a professor at the University of Brussels, installed the circle's provisional committee. Finally, Auguste Couvreur (1827-1894), an eminent liberal politician and member of the national parliament, gave another speech. The ceremony took place in the big town hall of Dendermonde, but no local elected representative or education activist actively took part in it. ${ }^{62}$ The same holds true with regards to the inauguration of the local circle in Uccle, Brussels, ${ }^{63}$ and the circle in the town of Namur, inaugurated in $1869 .^{64}$ The exclusion of local representatives from the inauguration ceremonies is emblematic of the unequal relationship between the League's General Council and its local branches. Local groups were not considered to be autonomous actors - they were appendices of the association's centre in Brussels.

The permanent local entrenchment of the French League can partly be explained by the fact that, from the beginning, the association lacked a central body. Jean Macé, who had to leave Paris after Louis-Napoléon Bonaparte's coup d'état in 1851, coordinated the League's first steps from his exile in the village of Beblenheim close to Colmar in Alsace. Because of the legal and political restrictions under the Second Empire, it was impossible to establish a genuine civil society association with an organisational centre in the capital. Instead, thanks to his contacts in the milieu of education reformists, Macé relied on the establishment of rather small and informal local circles that were spread all over the country. ${ }^{65}$ Local education associations had started to spring up in the 1860s when the Second Empire regime slightly released its grip on civil society organisations and even started to encourage private initiatives for the establishment of popular education. ${ }^{66}$ Along with the foundation of new local circles,

61 P. Desguin to Charles Buls, Liège, 21 April 1868, 501,II Sections locales, Ar.LB.

62 General Council, Invitation, Brussels, 25 January 1868, 501, II Sections locales, Ar.LB.

63 Local circle in Uccle, Invitation, Uccle, 14 April 1867, 501,I Sections locales, Ar.LB.

64 Local circle in Namur, Invitation, Namur, 8 March 1869, 501,I Sections locales, Ar.LB.

65 On the associational landscape, which came into being in the 19th century despite the hostile regimes, see: Maurice Agulhon, Le cercle dans la France bourgeoise (Paris: Imprimerie nationale, 1977). On the associational life on the countryside, see: Maurice Agulhon and Maryvonne Bodiguel, Les associations au village (Le Paradou: Actes Sud, 1981).

66 Agulhon and Bodiguel, Les associations au village, 12. 
Macé helped to found societies like the Société Franklin, the most important among the many public library associations. ${ }^{67}$ Thus, by the time the League was finally institutionalised under the Third Republic in 1881, there were already 350 local associations which were merely reorganised as a federation with a centre in Paris. ${ }^{68}$ Whereas local associations up until 1881 constituted the very essence of the French Education League, the Belgian ligueurs in Brussels had in mind a clear hierarchy between the association's centre and the local branches. According to the Belgian League's statutes and its practice, local circles had to regularly report to the General Council, follow its instructions, and were not supposed to act independently, for example to invite speakers to their seminars or other events. ${ }^{69}$ The control that the General Council exerted on the local circles can, especially when compared to the French League, be interpreted as one reason for the League's failure to grow real roots in the provinces. While in France, in the context of a repressive regime, education reformists were forced to adapt to local social and political patterns, this applies much less to the Belgian activists who could eventually rely on the increasing influence the League was having in Brussels.

The hierarchical relationship between the central committee and the local branches is even more remarkable if one takes into account the fact that most local activists had the same socio-political background as the members of the General Council in Brussels. This body and the committees of the local circles were characterised by their members' elitist, upper middle-class, or even noble backgrounds. ${ }^{70}$ The committee's composition in Veurne, West Flanders, is representative in this regard: Its president was a medical doctor, its vice-president a deputy of the public prosecutor, and the secretary and its representative agent were employed by the local secondary school. The first members of the circle were a lawyer and a music composer. ${ }^{71}$ The local circle in Perwez, Walloon Brabant, was driven by an aristocrat, ${ }^{72}$ and in the big municipality of Gembloux,

67 Katherine Auspitz, The Radical Bourgeoisie. The Ligue de l'Enseignement and the Origins of the Third Republic, 1866-1885 (New York/Cambridge: Cambridge University Press, 1982), 63. 68 Pierre-Emmanuel Raffi, Le temps des cercles. La Ligue de l'enseignement à Paris 1866-1881 (Paris: Imprimerie Idéalia, 1993), 132.

69 General Council, Circular to local circles, Brussels, 8 November 1868, 501,II Sections locales, Ar.LB.

70 Tyssens, Strijdpunt of pasmunt?, 236.

71 Local circle in Veurne to General Council, Veurne, 27 August 1869, 501,I Sections locales, Ar.LB.

72 Charles Buls and Jules Tarlier, Circular, Brussels, 30 December 1868, 501,II Sections locales, Ar.LB. 
Namur, the first committee of the local circle was composed of "government officials". ${ }^{73}$

The initiators of local circles focused their attention almost exclusively on local elites. They did so in two respects. First, the circles were administered by people with high social standing; second, the local committees tried to establish bonds with local political notabilities. ${ }^{74}$ Local reformers thought it was of primary importance to attract "people of influence",75 "distinguished people" and people of "some authority" who would support and thereby legitimise their movement. ${ }^{76}$ The mayor's attitude towards the Education League played a decisive role for many local activists. ${ }^{77} \mathrm{He}$ was perceived as the central contact person for the inauguration of a local circle, free public lessons, or public libraries. ${ }^{78}$ Activists believed that the political and social elite needed to approve of the circle's activity for education reform to attract some attention. In the town of St-Ghislain near Mons in Hainaut, Adolphe Laduron reported to Charles Buls the following: He had met Antoine Debruyn, who sat in the provincial council and was a member of the Education League's branch in the town of Mons. This politician had promised to circulate the League's recent petition among his colleagues, a petition that had already received the signatures of most "public figures" and the entire municipal council; ${ }^{79}$ all "men of influence" in the town were represented on it. ${ }^{80}$ In the East Flemish town of Dendermonde, the liberal municipal administration supported the League's education model - some coun-

73 Local circle in Gembloux to General Council, Gembloux, 24 August 1875, 501 Section locales, Ar.LB.

74 M. Gislain to General Council, Nil St. Vincent, 16 July 1866, 501,I Sections locales; Municipal administration Dendermonde to Local circle in Dendermonde, Dendermonde, 18 January 1868, 501,II Sections locales, Ar.LB.

75 General Council, Circular, Brussels, 10 May 1869; M. Nihoul to Charles Buls, Veurne, 13 February 1869; Local circle in Waterloo, Annual report, Waterloo, 7 May 1867, 501,I Sections locales, Ar.LB.

76 M. Behaers to Charles Buls, Nederzwalm, 25 february 1868, 501,I Sections locales, Ar.LB. 77 M. Gislain to General Council, Nil St. Vincent, 16 July 1866, 501,I Sections locales, Ar.LB. 78 Editor of Echo de la Frontière Belge to Charles Buls, Péruwelz, 11 November 1865; Local circle in Liège to Mayor, Liège, 31 January 1869, 501,I Sections locales, Ar.LB

79 Adolphe Laduron to Charles Buls, St. Ghislain, 03 July 1866, 800 Personnes physiques, Ar.LB.

80 Adolphe Laduron to Charles Buls, St. Ghislain, 21 August 1866, 800 Personnes physiques, Ar.LB. 
cillors were even part of the circle's committee - and made the city hall available for the circle's events. ${ }^{81}$

In fact, having a hall at their disposal was of crucial importance for the local circles, which contributed to their feeling of depending on the local elite's favour. ${ }^{82}$ The branch in Liège as well as the one in La Hestre, Hainaut, had to give up their work because they lacked the necessary financial support - not least to rent a hall for free evening classes. ${ }^{83}$ It was an exceptional case when a local branch, like the one in the town of Herstal, North of Liège, professed that it was independent from the municipal government, which had broken its promise to actively support the League. ${ }^{84}$ The activists perceived their forced submission to the local power structures as one of the main reasons for their failure to mobilise fellow townspeople, in particular members of the working classes. ${ }^{85}$ Working people did not join the League in any considerable numbers, as members or as attendees of the 'popular evenings' that the association offered as an alternative to the cabaret. ${ }^{86}$ Yet, a certain number of school teachers, whom the League consciously attempted to empower, welcomed and identified with the association. ${ }^{87}$ Teachers had something to gain: They complained about their poor working conditions and precarious economic situation and believed that the League could offer them some support in achieving these demands. ${ }^{88}$ The teachers, male and female, also lamented their dependence on the local clergy which, according to them, had been established by a royal decree of $1863 .^{89}$ This degree prescribed that the teachers' salary had to take into account the number of children who (regularly) attended classes. Teachers feared that the Catholic clergy

81 Local circle in Dendermonde, Annual report 1867-1868, Dendermonde, 21 July 1868; Local circle in Dendermonde to Charles Buls, Dendermonde, 08 January 1868, 501,II Sections locales, Ar.LB.

82 Local circle in Liège to Charles Buls, Liège, 7 February 1869, 501,I Sections locales, Ar.LB; Local circle in Liège, Annual report 1868-1869, Liège, 1869, 501,I Sections locales, Ar.LB.

83 Member in Leuven to General Council, Leuven, 14 June 1868, 501,II sections locales, Ar.LB; General Council, Circular, 10 May 1869, 501,I Sections locales, Ar.LB.

84 Member in Herstal to Charles Buls, Herstal, 12 December 1866, 501,I Sections locales, Ar.LB. 85 Member from Brussels to Local circle in Brussels, 1873; Local circle in Bruges, Circular to employers, Bruges, 30 November 1866, 501,I Sections locales, Ar.LB.

86 Local circle in Péruwelz, Circular, Péruwelz, 30 September 1888, 607,I Euvre nationale, Ar.LB.

87 Member in Bruges to Charles Buls, Bruges, 8 August 1865, Sections locales; M. de Dyck, Report on schools in West-Flanders, 18 November 1865, 601 Sections Commissions, Ar.LB.

88 François-Joseph Lagage to Charles Buls, Vimy, 8 January 1868, 401 Service de renseignement, Ar.LB.

89 Teacher in Liège to General Council, Liège, 27 December 1865; Teacher in Nederzwalm to Charles Buls, Nederzwalm, 7 November 1866, 501,I Sections locales, Ar. LB. 
would use its power to reduce the number of pupils by convincing parents to send their children to the confessional schools, thus reducing teachers' income. ${ }^{90}$

\section{Exposed to hostilities: The perception of the Catholic clergy's supremacy}

The Belgian Education League's main objective was to reform the education act of $1842,{ }^{91}$ a legal compromise between Liberals and Catholics from the time of unionism (1830-1846). ${ }^{92}$ Since 1846, the Liberals had been arguing against the law, which included the Catholic clergy's right to inspect the public schools and thereby exert influence on the public school teachers. ${ }^{93}$ The young 'progressive' liberals, many of whom were assembled in the Ligue de l'Enseignement, strongly opposed the clergy's intervention " $a$ toute autorité" in the public schools. ${ }^{94}$ It stood against their idea of a 'progressive' education which had to be secular, based on scientific knowledge and on a civic moral independent from religious dogma. ${ }^{95}$ The Catholic clergy, the League professed, was the major enemy of their endeavour to "spread the progress of science among the masses, to ameliorate people's material and moral conditions through education, and thereby prevent social upheavals". ${ }^{96}$ The Catholic church - if we be-

90 Teacher in Waterloo to Charles Buls, Waterloo, 1865, 501,I Sections locales, Ar.LB; Teacher in Waterloo to Primary School Section, Waterloo, 11 November 1865, 601 Sections Commissions, Ar.LB.

91 For a detailed presentation of the Education Act of 1842, see: Lory, Libéralisme et instruction primaire, I, 1-125.

92 Starting with the Liberals' coming to power in 1847, governments implemented programmes without discussing them with political adversaries as had usually been done in the times of Catholic-liberal unionism. See: Gubin and Nandrin, "La Belgique libérale et bourgeoise," 49. 93 For a general overview of the relationship between Church and State in 19th-century Belgium, see: Roger Aubert, "Kirche und Staat in Belgien im 19. Jahrhundert," in Beiträge zur deutschen und belgischen Verfassungsgeschichte im 19. Jahrhundert, ed. Werner Conze (Stuttgart: Klett, 1997), 5-25.

94 Lory, Libéralisme et instruction primaire, 51; Local circle in Liège to General Council, Liège, 26 September 1865, 601 Sections Commissions, Ar.LB. For more on these progressive liberals, see: chapter 1 /introduction to this volume.

95 Jean Stengers, "Der belgische Liberalismus im 19. Jahrhundert," in Liberalismus im 19. Jahrhundert. Deutschland im europäischen Vergleich, eds. Dieter Langewiesche and Jürgen Kocka (Göttingen: Vandenhoeck \& Ruprecht, 1988), 415-439, 432.

96 Local circle in Namur, Circular, Namur, 8 March 1869; Correspondent in Beauraing to Jules Tarlier, Beauraing, 27 November 1866, 501,I Sections locales, Ar.LB. 
lieve what Buls reported to Macé in 1867 - reacted by excommunicating the League's members. ${ }^{97}$ As a correspondent from La Hestre put it, the foundation of local circles had "fanned the flames of hatred" between the liberal and the Catholic camp in the municipalities. ${ }^{98}$ Local activists experienced the Catholic clergy's social supremacy - even though it might not have been as strong and systematic as professed by the progressive liberals ${ }^{99}$ - in two different ways. First, the public school teachers complained about their dependence on the clergy; they felt the churchmen's pressure when doing their daily work and thought that the clergy became especially watchful if a teacher was a member of a local League circle. Second, the initiators of local circles saw their business hindered by direct attacks from the clergy as well as by the general influence it exerted on the rural people. The opposition between the Catholic clergy and the liberal-minded supporters of the League determined the local activists' self-perception and the way they conceived of their individual and collective actions. The antagonism provided the main interpretative pattern, which gave sense to their lived experiences and to their reporting about it.

As stated in its statutes, the League was committed to improving public school teachers' working and living conditions and protecting teachers from the clergy's social pressure. The case of the public school teacher François-Joseph Lagage was emblematic of the Belgian League's efforts in this regard: employed in a public school in the village of Nimy-Maisières near Mons, Lagage had refused to accompany his school children to Mass and had therefore been suspended from his job - by the Minister of the Interior. ${ }^{100}$ In 1867 , the Education League sponsored a campaign initiated by the municipality's inhabitants to protest this suspension. Most importantly, the League signed a petition addressed to the Minister of the Interior. ${ }^{101}$ The General Council also gained the support of the local newspaper L'Organe de Mons and published its demands over a period of four years. ${ }^{102}$ Many teachers who joined the League apparently believed in the association's capacity to liberate them from their perceived subjection to the

97 Charles Buls to Jean Macé, Brussels, 8 April 1867, 99 Z Carton 6, Archives of the Institut Catholique (Ar.IC), Paris, France.

98 Member in La Hestre to Charles Buls, La Hestre, 9 March 1869, 501,I Sections locales, Ar.LB. 99 Lory, Libéralisme et instruction primaire, 51.

100 François-Joseph Lagage to Mayor, Nimy-Maisières, 20 September 1865, 401 Affaire Lagage, Ar.LB.

101 Petition to minister of the Interior, Nimy-Maisières, 17 February 1867, 401 Affaire Lagage, Ar.LB.

102 Central Council to Editor of L'Organe de Mons, Brussels, 14 August 1869, 607 Personnes morales, Ar.LB. 
Catholic clergy. ${ }^{103}$ This hostility strengthened the link between public school teachers and the Education League.

Some local activists saw the attacks from the clergy as an encouraging and motivating factor - and as a testimony to their significance. ${ }^{104}$ In most cases however, intimidation from the pulpit was considered dangerous, if the League was to maintain its local position. ${ }^{105}$ Many local correspondents wrote of their fear of losing their social standing as a result of clerical animosity towards the League. Some reported direct, libellous attacks against League members in general and against teachers in particular. Some teachers felt unable to combine membership in the League with the jobs upon which they relied financially. ${ }^{106}$ According to one teacher from Waterloo, Walloon Brabant, a public school teacher who had a family had only two alternatives: "either to vegetate or to fall on his knees before the clergyman and to stress religious topics in his classes". ${ }^{107}$ This formulation encapsulates the twofold constraints that shaped most local peoples' experience of the school conflict. Their respective roles in private and public life appeared inconceivable if not placed within the meaningful context of the clergy-liberals opposition. It was therefore by pointing to the clergy's supremacy that many local activists explained away their inability to organise local associational life. ${ }^{108}$

It became common practice in the reports to the General Council to justify the circle's unsuccessful endeavours as the result of an atmosphere of general hostility, which the activists fostered by their reporting of lived experiences. ${ }^{109}$ Constant reference to 'dangerous' working conditions not only gave significance to their - also failed - actions, but they also made their initiatives appear more

103 Teacher in Nederzwalm to Charles Buls, Nederzwalm, 7 November 1866, 501,I Sections locales, Ar.LB.

104 M. Vandervelde to Charles Buls, Kortrijk, 5 February 1869; M. Nihoul to Charles Buls, Veurne, 13 February 1869, Ar.LB; Correspondent in Nivelles to Charles Buls, Nivelles, 13 February 1869; Local circle in Menen, Annual report 1868-1869, Menen, 31 December 1869; M. Nihoul to Charles Buls, Veurne, 13 February 1869, 501,I Sections locales, Ar.LB.

105 M. Robert to Charles Buls, Perwez, 19 August 1866; M. Gislain to Charles Buls, Nil St. Vincent, 24 September 1866; Local circle in Bruges, Annual report 1876, Bruges, 29 August 1876, 501,I Sections locales, Ar.LB.

106 A. Frings to Charles Buls, Lincent, 21 September 1866; Local circle in Uccle, Invitation, Uccle, 14 April 1867, 501,I Sections locales; M. Loppens to Charles Buls, Ypres, 12 October 1866, 800 Personnes physiques, Ar.LB.

107 Teacher in Waterloo to Charles Buls, Waterloo, 1865, 501,I Sections locales, Ar.LB.

108 Editor of L'Indépendant du Luxembourg to General Council, Arlon, 25 April 1867, 501,I Sections locales, Ar.LB.

109 M. Loppens to Charles Buls, Ypres, 14 August 1866, 800 Personnes physiques, Arl.LB; Local circle in Liège, Annual report 1868-1869, Liège, 1869, 501,I Sections locales, Ar.LB. 
intriguing; many local activists were seemingly longing for attention from the League's centre. In the municipality of Nil-St.Vincent, Walloon Brabant, Charles Buls' correspondent referenced "slippery grounds" that obliged the League's sympathisers to be "very cautious and not to touch on political or religious subjects". ${ }^{110}$ A correspondent from Perwez asked Charles Buls to use his contacts with the liberal newspaper Liberté to enable him to publish an article. The published satire was meant to punish the clergy for having ridiculed the Education League. The local priests were not named or attacked directly. Instead, they were alluded to by similar-sounding names, so that the author could not be blamed for any insult. ${ }^{111}$

However, unlike the letter by the correspondent from Perwez, most of the reports from the provinces did not display any spirit of resistance. This was not the case in France. Jean Macé's correspondents, while being conscious about the repressive character of the Second Empire, hoped for its liberalisation; ${ }^{112}$ others were less optimistic but were used to resisting the regime by circumventing the legal and political restrictions. ${ }^{113}$ They constantly tried to find ways around the legal restrictions. ${ }^{114}$ While Belgium possessed a liberal constitution, the League's local activists, especially in villages, felt unable to act out their formal freedoms because of their experience of pressure exerted by local Church representatives. In fact, Belgium was not only one of the most liberal states in Europe, but also among the most Catholic countries north of the Alps where the Church made ample use of the opportunities created by the constitutional system. The reports Belgian bishops sent to Rome about the state of their diocese from the mid-1840s to the early 1860s emphasised the restoration of moral order in the countryside and the power of Catholicism to reduce and even marginalise dissent. ${ }^{115}$ Thus, the churchmen's general influence was perceived as inhibiting the work of local League circles because it made the local populations passive, uninterested in education questions. The resignation of a correspondent from the town of Arlon in the province of Luxembourg is representative in this regard. In a letter from 1867, he expressed regret that the people in Arlon were entirely "indifferent" towards the League's objectives because the Jesuits controlled the so-

110 M. Gislain to Charles Buls, Nil St. Vincent, 30 June 1866, 501,I Sections locales, Ar.LB. 111 M. Gislain to Charles Buls, Nil St. Vincent, 24 September 1866, 501,I Sections locales, Ar.LB. 112 M. Waller to Jean Macé, Voisinlieu, 29 November 1866, $99 \mathrm{Z}$ Carton 2, Ar.IC.

113 E. Heutte (?) to Jean Macé, Pont-Audemer, 16 November 1867, 99Z Carton 6, Ar.IC.

114 Editor of Coopération du Journal du Progrès Social to Jean Macé, Paris, 2 January 1867, 99Z Carton 6, Ar.IC.

115 Vincent Viaene, Belgium and the Holy See from Gregory XVI to Pius IX (1831-1859) (Leuven: Leuven University Press, 2001), 9, 171. 
cial life "as in many other localities". ${ }^{116}$ This social control was experienced and depicted in an even more virulent manner in the context of the school war. The impositions that this national conflict brought about in the villages is encapsulated by a reported episode from Perwez. When the local circle's secretary suffered from typhus, some country priests called his illness a punishment from God directed against the League in general. ${ }^{117}$

Even the relatively successful circle in Liège, which counted 180 members in $1866,{ }^{118}$ reported to the General Council that they "were fighting, among other things, against the public's indifference" and were "unable to defeat it". ${ }^{119}$ Indifference, the social evil that the Education League had set out to combat, was also considered a hostile force in its own right. ${ }^{120}$ But many activists blamed the Catholic national governments of the 1870s for having caused people's apathy ${ }^{121}$ and fear. ${ }^{122}$ Ironically, the antagonism from the French state, where it did not stamp out the movement, turned out be rather favourable to the development of a grassroots activities, which remained vital simply because they had to fear the government's repression.

In Belgium, in 1878, a number of local activists were convinced that with the new Liberal majority in the national parliament, the fear and passivity might vanish, allowing them to recruit more members. ${ }^{123}$ Indeed, the circles in Antwerp, Namur and Waterloo started over in $1878 .{ }^{124}$ At the same time, the Catholic party's success in the municipal elections was considered a major reason for the

116 Editor of L'Indépendant du Luxembourg to General Council, Arlon, 25 April 1867, 501,I Sections locales, Ar.LB.

117 M. Combeau to General Council, Perwez, 27 November 1866, 501,I Sections locales, Ar.LB. 118 Local circle in Liège, Report at General Assembly, Liège, 28 June 1866, 501,I Sections locales, Ar.LB.

119 Local circle in Liège to General Secretary, Liège, 28 August 1866; Local circle in Liège, Annual report 1868-1869, Liège, 1869, 501,I Sections locales, Ar.LB.

120 Karl Grün to Charles Buls, Liège, 22 January 1869; L. Bekaers to General Council, Nederzwalm, 7 January 1867; Local circle in Antwerp to General Council, Antwerp, 13 March 1881; Local circle in Liège, Report at General Assembly, Liège, 28 June 1866, 501,I Sections locales, Ar.LB.

121 Local circle in Gembloux to General Council, Gembloux, 24 August 1875; Local circle in Gembloux, Circular, Gembloux, 27 January 1875, 501,I Sections locales, Ar.LB.

122 Member in Veurne to Charles Buls, Veurne, 22 August 1875; M. Loppens to Charles Buls, Ypres, 12 October 1866, 501,I Sections locales, Ar.LB.

123 Ibid.

124 In Namur: local circle in Namur to Charles Buls, Namur, 20 December 1878; in Waterloo: local circle in Waterloo, Invitation, Waterloo, 1881; in Antwerp: local circle in Antwerp to General Council, Antwerp, 8 July 1878, 501,I Sections locales, Ar.LB. 
local circles' loss of members, ${ }^{125}$ among other difficulties. "Things turn into a critical stage”, reported a correspondent from Gosselies near Charleroi when referring to changes in the municipal council. ${ }^{126}$ The composition of the provincial executive was also seen as relevant to the local circles' development, because this committee chose the public school inspectors. ${ }^{127}$ Along with the Catholic clergy, local ligueurs saw the "powerful aristocracy" as inhibiting the expansion of "progress" through education. ${ }^{128}$ Additionally, "revolutionaries" and "democrats", some of whom were members of the League and who were ready to allow people to vote before they were sufficiently educated, acted against the League's endeavours. ${ }^{129}$ In fact, hostile forces dominated the local activists' minds and daily experience. This atmosphere of antagonism profoundly marked their correspondence with the General Council, as activists tried to make their difficult situation understood. While the local actors identified with the League's conception of 'progress through education', they considered the clergy's power overwhelming and felt unable to implement the League's agenda. But it was not simply powerful locals who stymied reform; correspondents pointed to reasons linked to the social life in villages and small towns to explain their failure.

\section{Social life in villages versus plans made in Brussels}

"On the countryside, you have to take the people as they are", stated Buls' correspondent in Nil-St.-Vincent in 1866, as an introduction to his reported endeavours to counter the clergy's attack with satirical newspaper articles. ${ }^{130}$ Local activists often explained how their activism was made difficult because of the assumed particularities of rural people. Reformers went to some length to depict their living conditions, describing the circumstances in villages and small towns along with their ideas about the mindset of rural people, all of which served to

125 Local circle in Menen, Annual report 1868-1869, Menen, 31 December 1869, 501,I Sections locales, Ar.LB.

126 Local circle in Gosselies, Annual report, Gosselies, 14 August 1868, 501,I Sections locales, Ar.LB.

127 M. Loppens to Charles Buls, Ypres, 12 October 1866, 501,I Sections locales, Ar.LB.

128 Member in Leuven to General Council, Leuven, 14 June 1868, 501,I Sections locales, Ar.LB. 129 Local circle in Liège to Charles Buls, Liège, 07 February 1869; Member in Liège to Charles Buls, Liège, 21 March 1868; G. Berger to Charles Buls, Wavre, 27 April 1867, 501,I Sections locales, Ar.LB.

130 M. Gislain to Charles Buls, Nil St. Vincent, 24 September 1866, 501,I Sections locales, Ar.LB. 
justify their failure to recruit members or to attract an audience to seminars and other events. Research has shown how $19^{\text {th }}$-century liberals and socialists in Ghent and Antwerp and in the capital Brussels regarded the surrounding countryside as backward territories which had to be civilised. ${ }^{131}$ After liberal street protests against the Catholic government in 1871, the internationally renowned economist Emile de Laveleye (1822-1892) described in an article how the political crisis was the symptom of a more fundamental imbalance in modern Belgian society which affected all Catholic countries:

\begin{abstract}
Always and everywhere rural people have had a different way of life and state of mind compared to city dwellers. The countryman lives isolated [...]. He opposes new ideas, mistrusts them. The working conditions of the peasant make him conservative, superstitious, and submissive to the clergy. [....] In the cities, on the contrary, new ideas penetrate quickly. Discussion, the exchange of ideas, [...] predispose the mind to change and progress. ${ }^{132}$
\end{abstract}

The local correspondents of the League insisted on the exhausting character of rural people's daily lives as the reason for their indifference towards education opportunities and the League's initiatives. In order to attract some followers, the local circles had to adapt to their town's daily life. The association also had to accommodate the rural seasonal rhythm. Therefore, the League's actions in the provinces and those in the capital were sometimes difficult to coordinate not in the least because differences were overemphasised by the local activists. In the municipality of Gembloux, the local circle suspended its business at the end of June 1875 and only started again in November. According to the local chairman, given "the heat, the agricultural work, and the holidays", it was pointless to organise any conference at this time of the year. ${ }^{133}$ The local branch in Gosselies, close to the industrial centre of Charleroi in Hainaut, suspended its activities until October, calling the month of August an "inopportune season" where no genuine public life was taking place. ${ }^{134}$ The inhabitants of Liège, who often combined a job in the industries with life on the countryside, were said by the local chairman to be out of town during the entire month of September, travelling or doing agricultural work. An assembly which the General Coun-

131 De Smaele, Rechts Vlaanderen, 356-357, 367, 371.

132 Emile de Laveleye, "La Crise de 1871 en Belgique, les causes et les périls de la situation," Revue des Deux Mondes, 2e période, vol. 197 (1872): 257. See also: De Smaele, Rechts Vlaanderen, 373.

133 Local circle in Gembloux to General Council, Gembloux, 24 August 1875, 501,I Sections locales, Ar.LB.

134 Local circle in Gosselies, Annual report, Gosselies, 14 August 1868, 501,I Sections locales, Ar.LB. 
cil, unfamiliar with Liège's calendar, had scheduled for September had therefore to be postponed. ${ }^{135}$ Local activists felt that actors in Brussels were acting completely unaware of their daily routines and constraints. This lived experience, alongside a certain degree of actual ignorance, perpetuated the continuous communication difficulties between the centre and the rural areas. Thus, a correspondent from Kortrijk in West-Flanders explained to Buls how conferences, if they are meant to integrate rural people, had to be organised to accommodate the daily routines of town residents. Conferences had to be planned for the days of the weekly market and scheduled for eight in the evening, just before the inhabitants of the surrounding localities who had done their shopping in the town would take their coaches back home. ${ }^{136}$

The League also had to adapt to the increasingly politicised public life in the municipalities. To legitimise the local circle's occasional inactivity and not without pride, correspondents pointed to the fact that public attention had been absorbed by another socio-political event, municipal elections in most cases. Election campaigns absorbed all attention and dominated public life so completely that it was pointless to organise other events while an election was ongoing. ${ }^{137}$ In the town of Verviers in the province of Liège, the correspondent reported that "at the end of the month, minds were entirely occupied by the municipal elections" as well as by the local choir competition. This was why the visit of a representative from the Central Council had to be rescheduled. ${ }^{138}$

Sometimes, local elections also collided with the League's projects in a very practical sense. The circle in Bruges reported that during the provincial election campaign it had been unable to organise seminars and meetings because the local meeting place had been occupied by the liberal associations. ${ }^{139}$ Some local circles, such as in Liège, were disturbed by the bad sanitary conditions in the towns, which could hinder the organisation of assemblies. ${ }^{140}$ In Perwez, too, the circle's activity was inhibited when its general secretary contracted typhus. ${ }^{141}$ The local ligueurs' perception of their fellow villagers and the supposi-

135 Local circle in Liège to General Secretary, Liège, 28 August 1866, 501,I Sections locales, Ar.LB.

136 M. Verbeke to Charles Buls, Kortrijk, 16 February 1869, 501,I Sections locales, Ar.LB.

137 Local circle in Antwerp to Charles Buls, Antwerp, 27 October 1878, 501,I Sections locales, Ar.LB.

138 Local circle in Verviers to General Council, Verviers, 24 February 1874, 501,I Sections locales, Ar.LB.

139 Local circle in Bruges, Annual report, Bruges, 7 October 1868, 501, I Sections locales, Ar.LB. 140 Local circle in Liège to General Secretary, Liège, 28 August 1866, 501,I Sections locales, Ar.LB.

141 M. Combeau to General Council, Perwez, 27 November 1866, 501,I Sections locales, Ar.LB. 
tion of their intellectual inferiority was another reason for the League's failure in the provinces. Correspondents identified a specific mindset and often alluded to the assumed simplicity, even backwardness of rural people. ${ }^{142}$ According to a correspondent from the small town north of Liège, the people in Herstal were simply unfamiliar with the idea of uniting forces to pursue a common goal. ${ }^{143}$ Another stated that the animosities and rivalries among people in small towns hindered the circle from flourishing because "those who might be interested in participating refrain from the circle because it had not been their own idea."144

Reformers also connected this assumed backwardness with a lack of local interest in free seminars and public lectures. Several local chairmen considered their fellow villagers as not yet 'ripe' for the League's political claims; many statements were simply too 'progressive' for them. As in fact, the meaningful context in which local activists placed their lived experiences were not only constituted by the clergy-liberals antagonism and the constraining living conditions on the countryside, but also, or perhaps particularly so, by the liberal-progressive ideology driving the Education League's project. Yet, they often felt obliged to differ from these principles, which further hampered their identification with the association. This aspect was particularly relevant given that the General Council chose the speakers for the local circles' public events. In this respect, the local chairman from Waterloo recommended that his colleagues in Brussels choose a speaker also able to address agricultural topics. He insisted that the speech had to be "amusing"; the speaker had to "entertain" the audience and bear in mind that he was not talking to "savants". ${ }^{145}$ A correspondent from the small town of Wavre, Walloon Brabant, reported a scene that was emblematic in this context. A distinguished French orator, the republican Noël Madier de Montjau (1814-1892), had given a "brilliant speech" at the local circle. However, ignoring the circle's convention not to address political and religious topics, Madier de Montjau had shocked the audience with "remarks far too advanced for the people from a town such as Wavre". His comments on the Catholic Church and on republicanism had alienated the audience. In order to avoid losing his membership, the correspondent had to promise not to invite the speaker again. However, contradicting his own words, the local activist concluded his letter by stating that "we are as advanced as M. Madier", but that such "extremist

142 See Stengers, “Der belgische Liberalismus im 19. Jahrhundert,” 431.

143 Member in Herstal to Charles Buls, Herstal, 12 December 1866, 501,I Sections locales, Ar.LB. 144 Editor of L'Indépendant du Luxembourg to General Council, Arlon, 25 April 1867, 501, I Sections locales, Ar.LB.

145 Local circle in Waterloo, Circular, Waterloo, 25 October 1865, 501,I Sections locales, Ar.LB. 
remarks" threatened the League's survival in the town. ${ }^{146}$ He tried to explain the circle's difficulties by pointing to local people's backwardness while at the same time repudiating such backwardness.

In its annual report from 1867, the local circle in Waterloo mentioned that it was probably the only circle "soundly entrenched in a rural municipality". ${ }^{147}$ In fact, the local activists demonstrated an awareness of the deep social and cultural divide between the General Council and the local branches. The association's central body also occasionally acknowledged this divide; in 1868, it invited the chairmen of all local branches to a banquet in Brussels in order to reunite the association and to demonstrate unity ${ }^{148}$ by employing a type of sociability adapted to the habits in small towns and rural regions. This capital-province divide had no direct equivalent in France, especially during the first years of the French Education League's existence. The fact that Jean Macé did not coordinate his project from a Parisian centre but from a village in Alsace surely made the establishment of local associations easier. His personal immersion in the rural world facilitated communication between the different branches of the League, a pattern of adaptation that the Belgian League seemingly lacked. The perceived cultural distance between the members of the General Council and the activists in the rural areas in particular contributed to the League's failure to entrench itself outside Brussels.

\section{Conclusion}

The local activists' experience was not in accord with the social and cultural practices of the Education League in Brussels where its representatives mostly communicated with government officials and with the capital's press. Reformists' experiences were deeply affected by local power structures, which they understood as dominated by the Catholic clergy. They were confronted with a rural mindset that seemed to clash with most aims and demands of the Education League. The League's plans for establishing a secular and state-sponsored education system was at odds with the lived experiences in the provinces. A primary education that would be compulsory for children and offered to adults in their free evenings, an education that would be underpinned by rationalist and nationalist thinking and by an ideology of progress, an elementary education that would

146 G. Berger to Charles Buls, Wavre, 27 April 1867, 501,I Sections locales, Ar.LB.

147 Local circle in Waterloo, Annual report, Waterloo, 7 April 1867, 501, I Sections locales, Ar.LB. 148 General Council, Invitation, Brussels, 2 September 1868, 501,II Sections locales, Ar.LB. 
form the future citizens of a 'democratic country' - so ran the League's ideas, to which very few people in the provinces eventually could subscribe. In fact, while the local activists had some success with gaining the support of local 'notabilities', they were unable to interest their fellow villagers or townspeople in the Education League's project to improve - and secularise - popular education. Therefore, according to the central committee's ideology of progress, country folk had to be considered as 'backward'. However, it would be mistaken to deduce from the often quoted 'lack of interest' of rural people that the education debate only took place in Brussels. Rather on the contrary, in small towns the school conflict was experienced by some as a risk to their private, social and professional lives. Local activists formed and expressed their experiences of their failing endeavours by referring to interpretative patterns such as the clergy-liberals antagonism, the specific living conditions of the countryside and the liberal-progressive ideology. Their experiences also took shape through the reporting and depicting of lived experiences in the many letters addressed to the League's General Council.

Due to the experiences of local actors, the objective to convince people of the importance and power of secular education was increasingly pursued in Brussels only. In contrast to its French equivalent, the Belgian League did not, in the long run, rely on the integration of the provinces or accommodate the rural areas with their specific circumstances. Instead, the League came to believe that its agenda was sufficiently represented by the General Council in Brussels - supposedly an embodiment of the nation as a whole. The central and provincial actors both perceived and through their communication perpetuated the gap and the hierarchy between the capital and the provinces. The French Education League, on the contrary, until the final installation of the Third Republic, depended on its decentralised character to escape repressive measures from the Second Empire. In the end, ironically, this repression produced a democratic organisational structure built to last. 
